\title{
Genetic Studies on Turcicum Leaf Blight Resistance of Maize (Zea mays L.)
}

\author{
Nandan L. Patil ${ }^{1 *}$, R.M. Kachapur ${ }^{2}$, M.C. Wali ${ }^{1}$, S.I. Harlapur ${ }^{2}$ and Sudha Nair ${ }^{3}$ \\ ${ }^{1}$ Department of Genetics and Plant Breeding, College of Agriculture, University of \\ Agricultural Sciences, Dharwad-580008, Karnataka, India \\ ${ }^{2}$ All India Co-ordinated Project on Maize (AICRP), University of Agricultural Sciences, \\ Dharwad-580008, Karnataka, India \\ ${ }^{3}$ CIMMYT, India, Hyderabad, Telangana, India \\ *Corresponding author
}

\section{A B S T R A C T}

Keywords

Turcicum leaf blight,

$\mathrm{R} \times \mathrm{S}$, Artificial

epiphytotic

Article Info

Accepted:

10 September 2018

Available Online:

10 October 2018
In the present study conducted at AICRP Maize, University of Agricultural Sciences, Dharwad, sixty single cross hybrids were produced by crossing twenty female inbred lines to three divergent inbred male testers in line $\mathrm{x}$ tester design. The parental inbred lines along with test cross hybrids, resistant check, susceptible check and hybrid checks were evaluated for their disease reaction against turcicum leaf blight under artificial epiphytotic condition. Among the inbred lines, TLB-2, TLB-5, TLB-6, TLB-9, TLB-12, TLB-19 and TLB-20 showed resistant reaction against disease. Among the tester CM-111 was moderately resistant, GPM-549 showed moderate susceptibility and GPM-581 was susceptible to disease. Promising female inbred lines such as TLB-6 and TLB-16 produced resistant hybrids irrespective of male testers. Relatively a higher proportion of susceptible hybrids were obtained as two of the three testers were susceptible to disease. The male parent played a crucial role in determining the disease reaction of hybrids.

\section{Introduction}

Maize (Zea mays L.) is a widely grown crop in Karnataka next to rice during kharif season. Maize belongs to grass family Poaceae and is a C4 crop showing significant positive response for application of chemical fertilizers and since it also a day neutral crop makes it an ideal crop to be cultivated across season and in varied agroclimatic conditions.

Karnataka is a major maize growing state in the country with productivity of 2.77 tons per hectare (Anon., 2016) and nearly 90 per cent of the total production of the state comes from kharif season. During the kharif season drizzling rain and high humidity creates ideal climatic condition for development of key foliar disease in maize namely turcicum leaf blight [Exserohilum turcicum (Pass.) Leonard and Suggs.].

In, Karnataka the yield loss due to this disease has been reported to range from 28 to 91 per cent (Pandurangegowda et al., 1993; Kachapur, 1988; Harlapur et al., 2000). The disease forms necrotic lesion on lower leaves and later spread to entire plant thereby 
reducing the photosynthetic area of leaves thereby affecting the grain filling stage of the plant leading to small sized, curved, partially filled and malformed chaffy cobs with shriveled grains. There are recommended package of practices such as seed treatment with fungicides and chemical sprays. But since majority of the maize area during kharif season is under rainfed ecosystem farmers are unable to take up recommended control measures with chemical fungicides because of their economic status and holdings of large area. Under such a situation farmer need resistant hybrids and host plant resistance breeding is economical and environmentally friendly method to check the spread of disease. Thus, objective of the present study was to identify resistant inbred lines and single cross hybrids against turcicum leaf blight on maize.

\section{Materials and Methods}

The present experiment was carried out at AICRP, Maize, UAS Dharwad, Karnataka situated at $15^{\circ} 26^{\prime} \mathrm{N}$ latitude and $75^{\circ} 07^{\prime} \mathrm{E}$ longitude with an altitude of $678 \mathrm{~m}$ above mean sea level and mean annual rainfall of $740 \mathrm{~mm}$.At AICRP, Maize in collaboration with CIMMYT nearly hundred lines were screened for TLB over a period of two years during kharif 2015 and 2016 under artificial epiphytotic condition and out of these twenty lines were selected based on their perse performance and disease reaction to turcicum leaf blight (TLB). These selected twenty lines were crossed to three diverse testers CM-111, GPM-549 and GPM-581 in line x tester design to produce sixty test cross hybrids.

All the sixty hybrids along with inbred lines and hybrid checks namely GPMH-1101 (Local check), NK-6240 (National check) and 900 M (Private check) were raised in a single row of four meter length consisting of 20 plants per row by following a spacing of $60 \mathrm{~cm}$ x $20 \mathrm{~cm}$ in the experiment. Resistant check CI-4 and susceptible check CML-451 were interspersed among the genotypes in the experiment. The Exserohilum turcicum culture multiplied on sorghum grains with disease inoculum of previous year infected leaves. The crop was artificially inoculated at 30 to 40 DAS following whorl-drop method of inoculation (Frederiksen and Franklin, 1978). The plants were sprayed with water to create a humidity for spore germination and infection. Five randomly selected plants were scored during dry silk stage (DAS 85-90) for their disease severity on scale 1 (Resistant) to 9 (Susceptible) (Anon., 2016).

\section{Results and Discussion}

Among the parental inbred lines eight lines were resistant, six were moderately resistant, eight were moderately susceptible and one was susceptible. Disease reaction of the inbred lines, testers along with resistant and susceptible check is presented in Table 1. Among the lines, TLB-2, TLB-5, TLB-6, TLB-9, TLB-12, TLB-19 and TLB-20 showed resistance to turcicum leaf blight. While TLB3, TLB-7, TLB-8, TLB-10, TLB-11, TLB-23 and TLB-24 were moderately resistant to disease. None of the lines were susceptible to disease. Among the testers, CM-111 was moderately resistant, GPM-549 was moderately susceptible and GPM-581 showed susceptibility against disease. Similarly, Mallikarjuna (1997) also reported CM-111 to be moderately resistant.

A total of ten hybrids showed resistance reaction against turcicum leaf blight (Table 3) while thirteen hybrids were moderately resistant, twenty-eight moderately susceptible and nine were susceptible to disease (Table 2). Local check GPMH-1101 showed moderate resistance, national check NK-6240 was moderately susceptible and private check 900 $\mathrm{M}$ was susceptible to turcicum leaf blight. 
Table.1 Disease score and disease reaction of 23 inbred lines along with resistant and susceptible check

\begin{tabular}{|c|c|c|c|}
\hline SI. No. & Inbred & Disease score $(1-9)$ & Disease reaction \\
\hline \multicolumn{4}{|c|}{ Lines } \\
\hline 1. & TLB-2 & 3 & Resistant \\
\hline 2. & TLB-3 & 4 & Moderately resistant \\
\hline 3. & TLB-5 & 2 & Resistant \\
\hline 4. & TLB-6 & 3 & Resistant \\
\hline 5. & TLB-7 & 6 & Moderately susceptible \\
\hline 6. & TLB-8 & 6 & Moderately susceptible \\
\hline 7. & TLB-9 & 4 & Resistant \\
\hline 8. & TLB-10 & 5 & Moderately resistant \\
\hline 9. & TLB-11 & 4 & Moderately resistant \\
\hline 10. & TLB-12 & 3 & Resistant \\
\hline 11. & TLB-13 & 7 & Moderately susceptible \\
\hline 12. & TLB-14 & 6 & Moderately susceptible \\
\hline 13. & TLB-16 & 6 & Moderately susceptible \\
\hline 14. & TLB-17 & 6 & Moderately susceptible \\
\hline 15. & TLB-19 & 3 & Resistant \\
\hline 16. & TLB-20 & 3 & Resistant \\
\hline 17. & TLB-21 & 6 & Moderately susceptible \\
\hline 18. & TLB-22 & 2 & Resistant \\
\hline 19. & TLB-23 & 5 & Moderately resistant \\
\hline 20. & TLB-24 & 5 & Moderately resistant \\
\hline \multicolumn{4}{|c|}{ Testers } \\
\hline 21. & CM-111 & 5 & Moderately resistant \\
\hline 22. & GPM-549 & 6 & Moderately susceptible \\
\hline \multirow[t]{3}{*}{23.} & GPM-581 & 8 & Susceptible \\
\hline & CI-4 (Resistant check) & 5 & Moderately resistant \\
\hline & CML-451 (Susceptible check) & 8 & Susceptible \\
\hline
\end{tabular}

Table.2 Disease reaction of parental inbreds and experimental single cross hybrids

\begin{tabular}{|c|c|c|c|}
\hline $\begin{array}{c}\text { Sl. } \\
\text { No. }\end{array}$ & Disease Reaction & No. of parental inbreds & $\begin{array}{c}\text { No. of single cross } \\
\text { hybrids }\end{array}$ \\
\hline 1. & Resistance (1-3) & 8 & 9 \\
\hline 2. & $\begin{array}{c}\text { Moderately Resistance (4- } \\
\text { 5) }\end{array}$ & 6 & 10 \\
\hline 3. & $\begin{array}{c}\text { Moderately Susceptible (6- } \\
\text { 7) }\end{array}$ & 8 & 13 \\
\hline 4. & Susceptible (7-8) & 1 & 28 \\
\hline
\end{tabular}


Table.3 Single cross hybrids showing resistance reaction against turcicum leaf blight

\begin{tabular}{|c|c|c|c|}
\hline Hybrids & Pedigree & $\begin{array}{c}\text { Disease } \\
\text { score }(\mathbf{1 - 9})\end{array}$ & $\begin{array}{c}\text { Grain yield under optimum } \\
\text { conditions (q/ha) }\end{array}$ \\
\hline GH-1641 & TLB-16 x GPM-549 & 2 & 63.99 \\
\hline GH-1615 & TLB-6 x TLB-581 & 3 & 60.09 \\
\hline GH-1614 & TLB-6 x GPM-549 & 3 & 68.40 \\
\hline GH-1623 & TLB-9 x GPM-549 & 3 & 53.88 \\
\hline GH-1610 & TLB-5 x CM-111 & 3 & 60.30 \\
\hline GH-1613 & TLB-6 x CM-111 & 3 & 61.87 \\
\hline GH-1622 & TLB-9 x CM-111 & 3 & 75.08 \\
\hline GH-1625 & TLB-10 CM-111 & 3 & 62.29 \\
\hline GH-1640 & TLB-16 x CM-111 & 3 & 56.31 \\
\hline GH-1646 & TLB-18 x CM-111 & 3 & 54.11 \\
\hline
\end{tabular}

Table.4 Number of hybrids under R x MR and R x S type of crosses

\begin{tabular}{|c|c|c|c|c|c|}
\hline & $\mathbf{R}$ & MR & MS & $\mathbf{S}$ & Total \\
\hline \multirow[t]{2}{*}{ R X MR } & 3 & 1 & 4 & 0 & \multirow[t]{2}{*}{8} \\
\hline & \multicolumn{2}{|c|}{$50 \%$} & \multicolumn{2}{|c|}{$50 \%$} & \\
\hline \multirow[t]{2}{*}{ R X S } & 1 & 1 & 5 & 1 & \multirow[t]{2}{*}{8} \\
\hline & \multicolumn{2}{|c|}{$20 \%$} & \multicolumn{2}{|c|}{$80 \%$} & \\
\hline
\end{tabular}

Table.5 Pedigree information of promising lines with resistance to turcicum leaf blight

\begin{tabular}{|c|c|c|c|c|}
\hline Line & Entry No. & $\begin{array}{c}\text { Source } \\
\text { Germplasm }\end{array}$ & $\begin{array}{c}\text { Description of source } \\
\text { population }\end{array}$ & $\begin{array}{l}\text { Description of } \\
\text { inbred }\end{array}$ \\
\hline TLB-6 & VL-1018527 & P47 & $\begin{array}{l}\text { Temperate/subtropical, } \\
\text { intermediate maturing with deep } \\
\text { white dent kernel and has been } \\
\text { improved for resistance to south } \\
\text { western corn borer and } E \text {. } \\
\text { turcicum. }\end{array}$ & $\begin{array}{l}\text { Line derived from } \\
\text { CML-317 } \\
\text { And belongs to sub- } \\
\text { tropical. White, flint } \\
\text { type, heterotic group } \\
\text { sub-tropical B1. }\end{array}$ \\
\hline TLB-16 & VL-0536 & Pop. ZM609 & $\begin{array}{l}\text { It is intermediate in maturity } \\
\text { with good resistance to maize } \\
\text { streak virus, E. turcicum and } P \text {. } \\
\text { sorghi. }\end{array}$ & $\begin{array}{l}\text { Line derived from the } \\
\text { cross (CML- } \\
\text { 389/CML-176) } \\
\text { Female parent: } \\
\text { CML-389 is of } \\
\text { African origin, late } \\
\text { maturing white grain, } \\
\text { flint type and belongs } \\
\text { to heterotic group } \\
\text { sub-tropical A1. } \\
\text { Male parent: CML- } \\
\text { 176 is a sub-tropical } \\
\text { line, white grain, flint } \\
\text { type and belongs to } \\
\text { heterotic group B1. }\end{array}$ \\
\hline
\end{tabular}

Source: CIMMYT 
Fig.1 Frequency distribution of hybrids from disease scale of 1 to 9

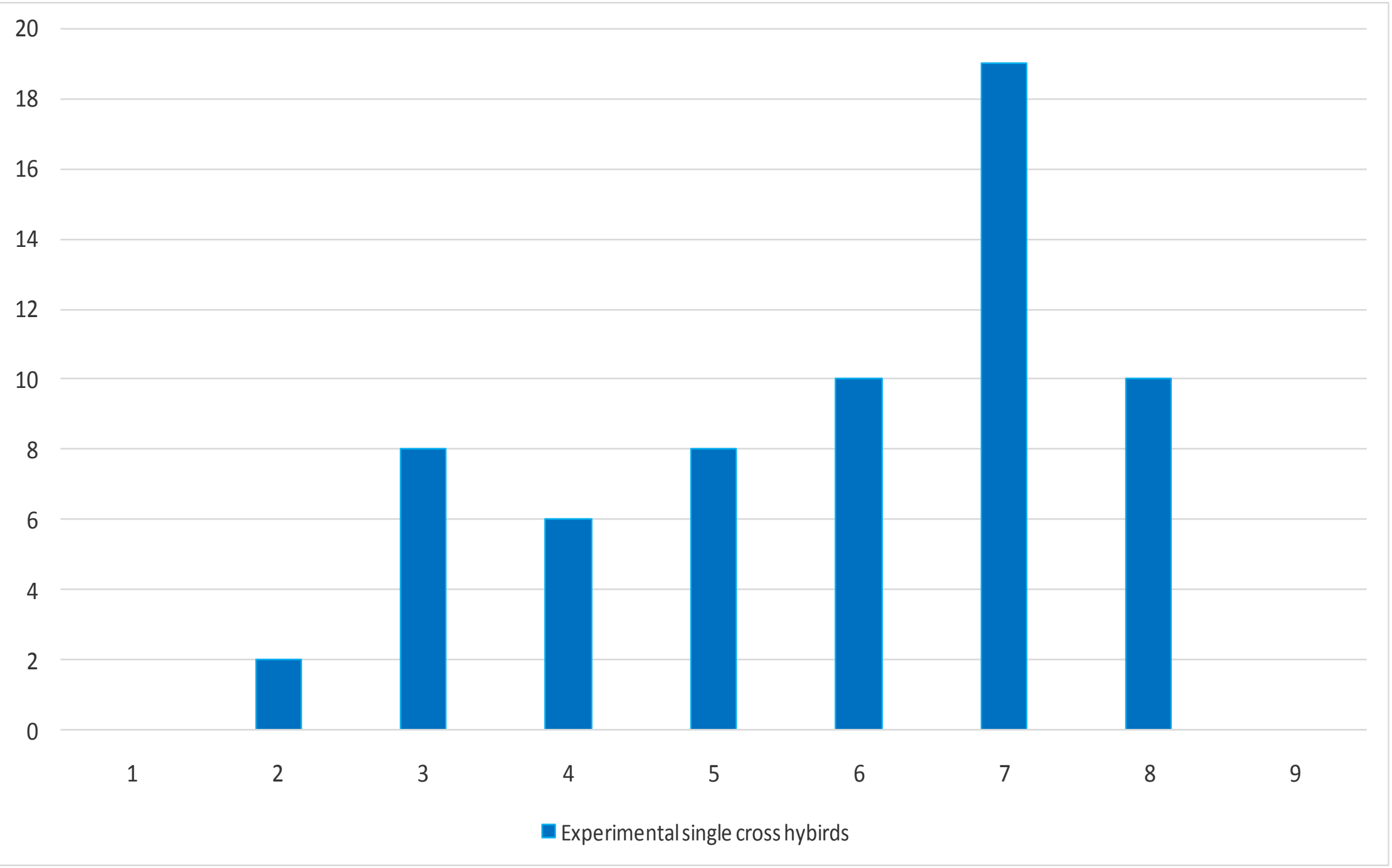



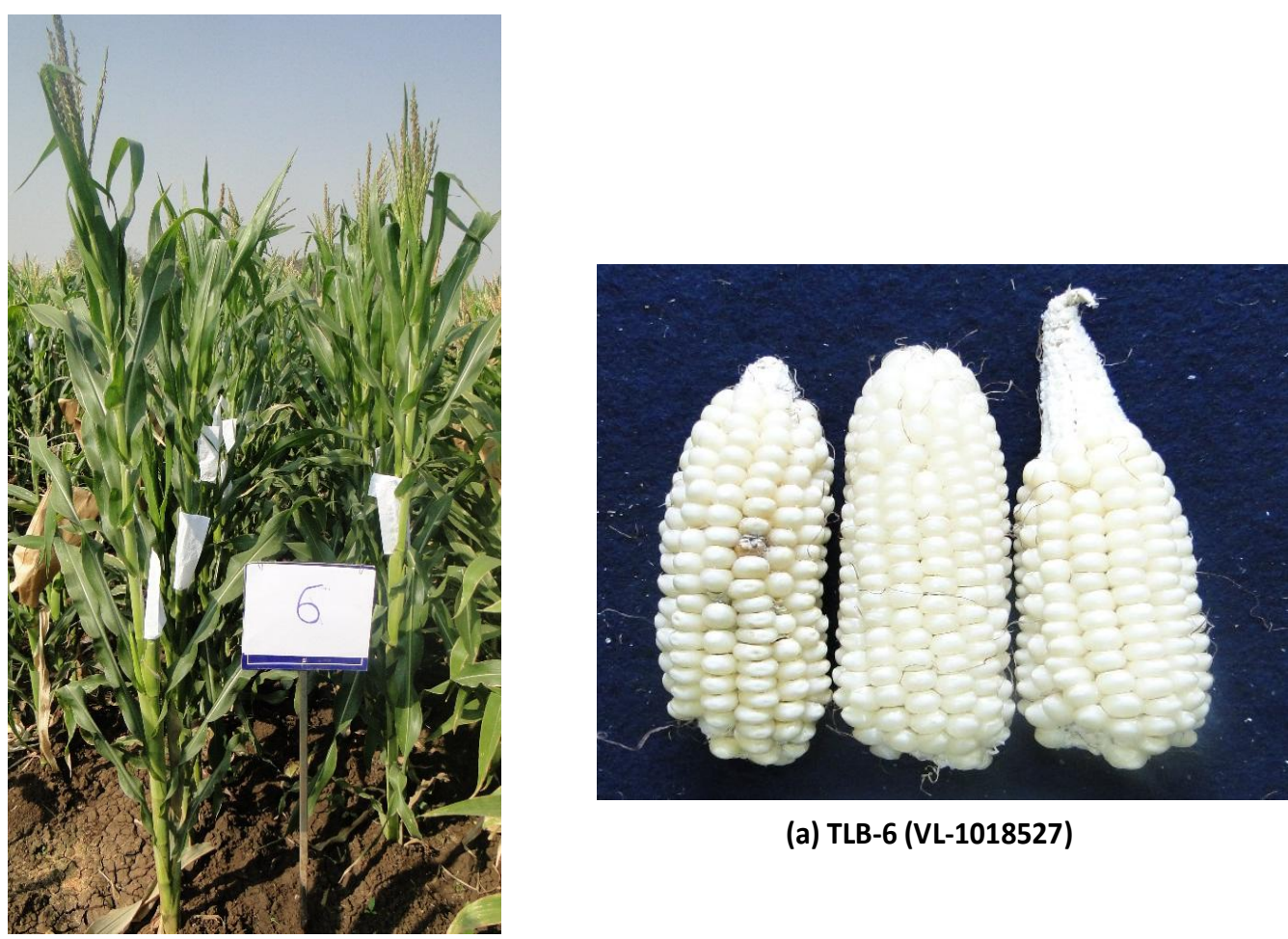

(a) TLB-6 (VL-1018527)
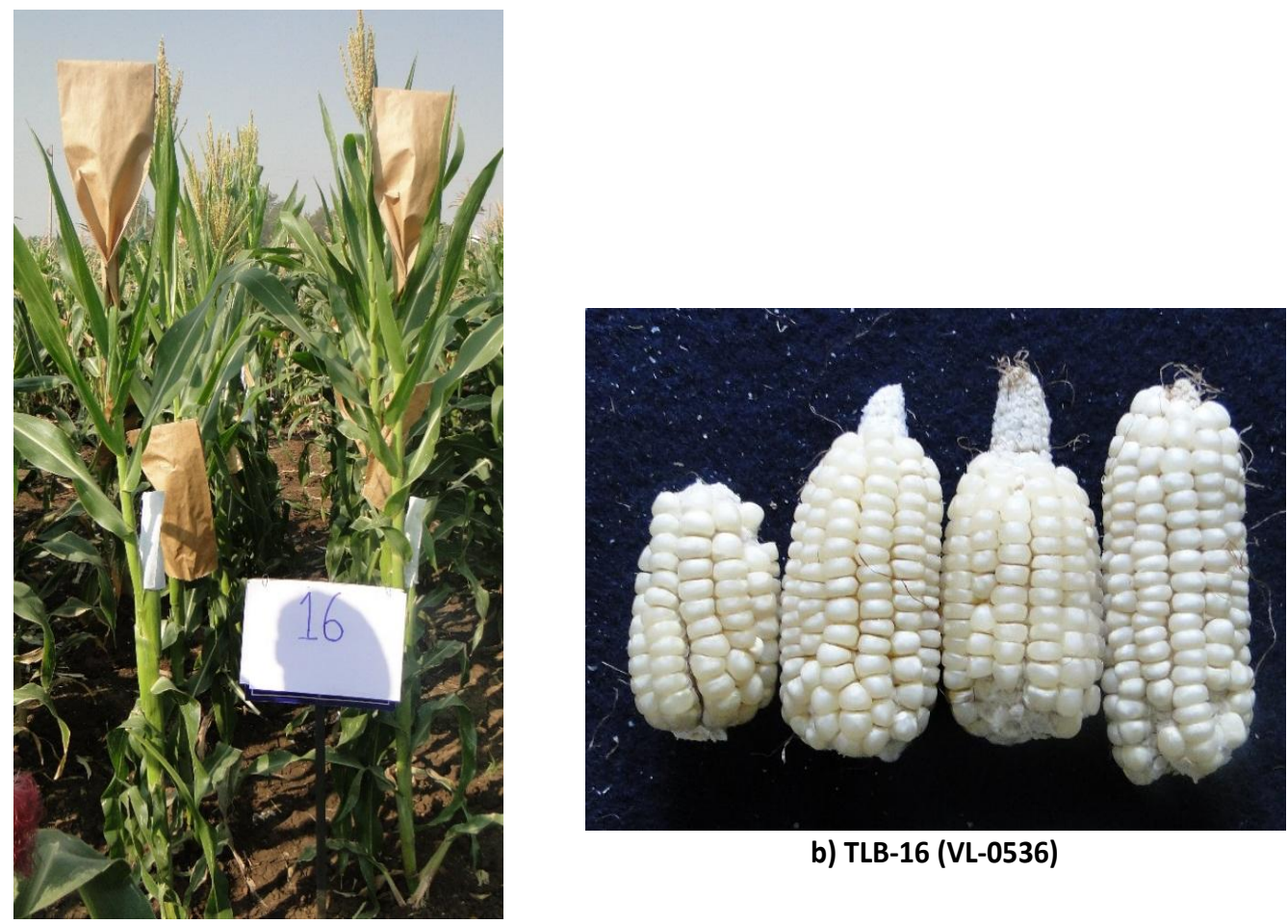

b) TLB-16 (VL-0536)

Figure 1. Lines with unique alleles for resistance against turcicum leaf blight. 
Among the hybrids with GPM-549and GPM581 as male parents $55 \%$ and $80 \%$ of the hybrids were moderately susceptible and susceptible to disease respectively. From the frequency distribution graph (Figure 1) it can be observed there are relatively a higher number of hybrids were with disease score of 6, 7 and 8 which fall under moderately susceptible (MS) and susceptible (S) category. These many high numbers of MS and $\mathrm{S}$ hybrids can be due to allelic contribution from moderately susceptible tester GPM-549 and susceptible tester GPM549. Thus, most of the hybrids produced from these testers show susceptible reaction against the disease. From this disease reaction it could be observed that the contribution of male parent has played a crucial role in determining the disease reaction of hybrids.

Based on the disease reaction to turcicum leaf blight the hybrids were classified into R $\mathrm{x}$ MR and $\mathrm{R} \times \mathrm{S}$ type of crosses (Table 4). From the eight $R \times$ MR type of crosses among the resulting hybrids three were resistant, one was moderately resistant and four showed moderate susceptibility to disease. Though all the hybrids produced from $\mathrm{R} \times \mathrm{MR}$ type of cross would be expected to be resistant but some of the hybrids showed deviation from the expected level of resistance which could be probably due to epistasis (Muiru et al., 2010, Castiano et al., 2012 and Sartori et al., 2015). Resilience to TLB is controlled by many genes (polygenic) so that many genes interact each other during the crossing between progenitors.

Among the inbred lines, TLB-6and TLB-16 as female parents in cross combination with any of the testers resulted in resistant hybrids (Figure 1). Pedigree wise these lines are tropical with white background and are good source of unique alleles which are dominant for resistance against turcicum leaf blight (Table 5). However, they need to be further validated using TLB specific markers and they can be used to develop base population for turcicum leaf blight resistance in addition with other resistant lines. The lines could also be further used to transfer unique alleles into established inbred lines through back crossbreeding. As reported by Ullstrup 1970, monogenic resistance confers less protection to the host than polygenic resistance under conditions of heavy epiphytotic of northern corn leaf blight. Hence breeding for TLB tolerance must be directed in having polygenic resistance to manage disease effectively.

In the present study the disease reaction of male parent has played acrucial role in determining the resistance of single cross hybrid. Promising inbred lines TLB-6 and TLB-16 are a source of unique alleles for production resistant single cross hybrids. These lines could be further be used in back breeding to transfer resistant alleles and for synthesizing base population to extract new inbred lines having resistance turcicum leaf blight. A higher proportion of resistant hybrids can be obtained if both male and female parent show resistant reaction against turcicum leaf blight.

\section{Acknowledgement}

It is hereby acknowledged for the material shared for carrying out the research work was part of the UASD-CIMMYT collaborative project being operated at AICRP, Maize, UASD.

\section{References}

Anonymous, 2016, Anu. Rep. (2016-2017), All India Coordinated Maize Improvement Project. Ludhiana, p. 10.

Castiano B. L., Edema R. and Asea G., 2012. Early-generation testing for Developing Maize Inbreds with Drought Tolerance 
and Resistance to Turcicum Leaf Blight and Streak Virus in Uganda. Proceeding of Third RUFORUM Biennial Meeting, 24-28 September 2012, Entebbe, Uganda.

Frederiksen, R.A., and Franklin Denis, 1978, In: Sorghum Diseases - A World Review (Williams, R. J. et al., eds.) Proceedings of the International Workshop at ICRISAT, 11-15 December, pp. 265-268.

Harlapur, S.I., Wali, M.C., Anahosur, K.H. and Muralikrishna, S., 2000, A reporton survey and surveillance of maize diseases in northern Karnataka. Karnataka Journal of Agricultural Sciences, 13: 750-751.

Kachapur, M. R., 1988, Studies on turcicum leaf blight of maize caused by Exserohilum turcicum (Leonard and Suggs.) with special reference to crop loss assessment. Ph. D. Thesis, Univ. Agric. Sci. Dharwad, Karnataka (India).

Khot, G. G., Teli, V. S., Kumbhar, C. T., Patil, V. S. and Deokar, A. T., 2005, Reaction of maize lines to turcicum leaf blight caused by Exoserhilum turcicum (Pass.) Leonard and Suggs. Karnataka J. Agric. Sci., 18 (4): 1123-1125.

Leonard, K. J. and Suggs, E. G., 1974, Setosphaeriaprolata is the ascigenous state of Exserohilum prolata. Mycologia, 66: 181-297.

Mallikarjuna, N., 1997, Studies on partial resistance to turcicum leaf blight of maize. M. Sc. (Agri.) Thesis, Univ. Agric. Sci., Bangalore, Karnataka (India).

Muiru W. M., Koopmann B., Tiedemann A. V., Mutitu E. W., and Kimenju J. W., 2010. Race typing and evaluation of aggresiveness of Exerohilum turcicum isolates of Kenyan, German and Austrian Origin. World J. Agric. Sci. 6(3): 277-284

Pandurangegowda, K.T., Shetty, H.S., Jayaramegowda, G. and Sangamlal, 1993, Incidence of turcicum leaf blight of maize in southern Karnataka. Current Research, 22: 100-101.

Sartori M. A., Nescia A., Formentoc A. and Etcheverry M., 2015. Selection of potential biological control of Exserohilum turcicum with epiphytic microorganisms from maize. Rev. Argent. Microbiol. 47 (1): 62-71.

Ullstrup, A. J., 1970, A comparison of monogenic and polygenic resistance to Helminthosporium turcicum in corn. Phytopathology, 60: 1597-1599.

\section{How to cite this article:}

Nandan L. Patil, R.M. Kachapur, M.C. Wali, S.I. Harlapur and Sudha Nair. 2018. Genetic Studies on Turcicum Leaf Blight Resistance of Maize (Zea mays L.). Int.J.Curr.Microbiol.App.Sci. 7(10): 989-996. doi: https://doi.org/10.20546/ijcmas.2018.710.110 